\title{
Resource use efficiencies as indicators of ecological sustainability in potato production: a South African case study
}

J.M. Steyn ${ }^{a,{ }^{*}}$, A.C. Franke ${ }^{b}$, J.E. van der Waals ${ }^{a}$, A.J. Haverkort ${ }^{a, c}$

${ }^{a}$ Department of Plant and Soil Sciences, University of Pretoria, Private Bag X20, Hatfield 0028, South Africa

${ }^{\mathrm{b}}$ Department of Soil, Crop and Climate Sciences, University of the Free State, PO Box 339, Bloemfontein, South Africa

${ }^{\mathrm{C}}$ Plant Research International, Wageningen University and Research Center P.O. Box 16, 6700 AA, Wageningen, the Netherlands

* Corresponding author: martin.steyn@up.ac.za

\section{ABSTRACT}

Potato, the most important vegetable crop in South Africa, is produced in many distinct geographical regions differing in climate, soils, production seasons and management practices and access to markets. These differences affect the amount of input resources required to produce potatoes as well as yields and crop value, and therefore the use efficiencies of land, water, nutrients, seed and energy. Resource use efficiencies affect the ecological and financial sustainability of potato production in this region, which has in general less favourable potato growing conditions than north-western Europe and the U.S.A., where high resource use efficiencies are usually recorded. This study aimed to assess and benchmark South African potato production regions, representing a wide range of growing conditions, regarding their use of input resources and to identify resource-intensive practices, which may suggest inefficient use of inputs. Surveys were conducted in 2013 and 2014 by interviewing growers in all production regions, to provide data on resource use efficiencies. Quantitative modelling approaches were applied to calculate carbon footprints as a proxy of 
energy use efficiency, potential crop yields and irrigation needs for each region. Variability in the gap between potential and actual yield was used to identify yield limiting factors. Actual yields achieved were on average $60 \%$ of the potential yield, suggesting fairly efficient use of available production factors. Water, seed and nutrient use efficiencies differed widely between and within regions and were not directly proportional to water requirements and yields achieved. Fertilizers (34\%) and irrigation (30\%) were the greatest contributors to energy use in potato crop production. Energy required to pump water was strongly related to the amount of irrigation applied, pumping depth and distance. Long distance travel of produce to retail points contributed substantially to energy use. Significant improvements in efficiencies are possible by improving management practices. Analysis of the variability in resource use efficiencies between farms and regions provided production sustainability indicators that can assist growers in identifying inefficient practices and yield limiting factors. These can be addressed through the use of decision support systems, such as irrigation scheduling tools, to improve resource use efficiencies and the sustainability of production, not only for the production efficiency of the specific study area, but also for the economic efficiency of potato production anywhere else.

Keywords: agricultural input, agro-ecological zones, yield potential, crop model, competitiveness, yield gap analysis, carbon footprint

\section{Introduction}

Potato is the fourth most important food crop in the world (FAOStat, 2016). Egypt is the leading producer in Africa in terms of volume of potatoes produced, followed by Algeria, Malawi, South Africa, and Rwanda (FAOStat, 2016). Of these countries, South Africa has the smallest production area (about 50000 ha), but highest average yields (about $43 \mathrm{t} \mathrm{ha}^{-1}$ ). Potato is produced in 16 geographically and edaphically distinct regions of South Africa (Figure 1; Table 1). The main growing regions are located in the eastern and western Free 
State, northern Limpopo and the Sandveld, but sizeable production also occurs in other parts of the country. Commercial potato growers in South Africa are generally skilled and have access to first world crop production and protection technologies. Potato is usually produced under irrigation due to low and unreliable rainfall, with the exception of the eastern Free State where dryland production is dominant. Limited supplementary and full irrigation occurs in this region when irrigation water is available. The availability of irrigation water is limiting in almost all production regions, but especially in regions relying on boreholes as water source (e.g. Limpopo and North West). In most inland regions (except Limpopo) potato production is limited to the summer season due to winter frost. As a result, crops are often exposed to unfavourably high daytime temperatures, which limits productivity. Sandy soils are generally preferred for potatoes, but soils vary substantially between regions. In the Sandveld and Ceres regions the soils are very sandy with low water and nutrient holding capacity, which complicates management. The diversity in growing regions and planting times ensures that fresh potatoes can be supplied to the market all year round (Potatoes South Africa, 2015).

Potato is a high-yielding crop, but its production requires relatively high uses of inputs such as water, seed, crop protection agents, energy and fertilizers (Sincik et al., 2008). The amount of inputs needed to produce a given amount of potato, also referred to as the resource use efficiency, affects the ecological and financial sustainability of production. Although potato yields and sales in South Africa have gradually increased over the past decade (Potatoes South Africa, 2015), the potato sector is facing serious concerns about the financial sustainability of production. Costs of most inputs, especially energy (both direct fuel and electricity cost, and the indirect cost of chemicals and fertilizers) have risen dramatically over the past decade (Strydom and van Zyl, 2015). This sharp increase in production costs, combined with a stagnation in product prices is detrimental to the financial sustainability of potato production. For example, in 2015 the average operating input cost per hectare for a target yield of $65 \mathrm{t} \mathrm{ha}^{-1}$ in the North West region amounted to 14,030 US $\$$, with gross income of 15,660 US $\$$, resulting in a gross profit of only about 1,630 US $\$$ per hectare. It should be 
clear that if target yields are not achieved, or product prices drop due to over-supply to the markets, the profit can easily turn into a loss (Pieter van Zyl, personal communication). As a result of this harsh economic environment, the number of commercial growers in South Africa has declined by about $50 \%$ in the past decade. The international competitiveness of potato industries in developing countries (e.g. in South America and Africa) is also of concern to domestic growers (Haverkort et al., 2014). In South Africa, for example, the processing of raw potato tubers into frozen products is currently only economically viable due to tariff walls protecting the domestic market against cheaper imports from north-western Europe. These tariffs protection measures are unsustainable in the long term.

Climate change is also expected to impact the sustainability of potato production globally. Potato is a heat-sensitive crop and in regions where it is presently being produced under relatively warm conditions, increased heat stress is expected to reduce yields (Haverkort et al., 2013; 2015) and therefore income per unit input. In cooler regions, or where production can be shifted to cooler seasons, however, the positive impacts of increased $\mathrm{CO}_{2}$ levels on potato yield and water use efficiency may override the negative impacts of increased temperatures (Franke et al., 2013). Furthermore, pest and disease pressure on potato crops is expected to increase as a result of higher temperatures in southern Africa (van der Waals et al., 2013), and therefore crop protection measures will further add to input costs. Since potato growers have little control over the cost of inputs, the best strategy to improve financial (and ecological) sustainability is to optimise the output (i.e. optimize yield and quality) for maximum income per unit input, i.e. to farm more efficiently (De Koeijer et al., 2003; De Wit, 1992; Nyagaka et al., 2010).

Input resource use efficiencies are often used as indicators of production-ecological sustainability of crop production (de Vries et al., 2010; van Ittersum and Rabbinge, 1997). Van Asselt et al. (2014), on the other hand, proposed a framework for the evaluation of sustainability of agri-food production systems, which also includes aspects not directly related to production efficiency and sustainability (e.g. food quality and safety, human health, 
animal and human welfare). Although resource use efficiencies do not cover all aspects of ecological or environmental sustainability, such as biodiversity impacts of land use or animal welfare, they have the advantage of being relatively easy to quantify and facilitate comparisons between crops, growers and regions (Franke et al., 2011).

A previous study that was limited to the Sandveld region of South Africa showed large differences among potato growers in the use efficiency of land, water, fertilizer, and biocides, despite the fact that they were farming under relatively homogenous agro-ecological conditions (Franke et al., 2011). This suggested that there is considerable scope for some individual growers to improve input use efficiencies per unit of potato produced. Besides the above-mentioned study, literature on the variability in input resources within and between diverse production regions, and their effect on input use efficiencies and overall sustainability of crop production of a region or country are scanty. A study was consequently initiated with the objective of quantifying and understanding variability in the use and use efficiencies of land, water, nutrients, energy and seed among potato growers within and between production regions in South Africa. A survey was employed to capture actual input levels per individual grower in each production region and a crop growth model was used to calculate the yield gap between actual and potential yields (van Ittersum et al., 2013). The information generated by this survey should enable growers to benchmark their efficiency of production and overall production sustainability relative to other growers in the same region and between regions. This also serves as a tool to identify input intensive activities and explore management options that could improve resource use efficiencies and economic competitiveness of the industry as a whole. 


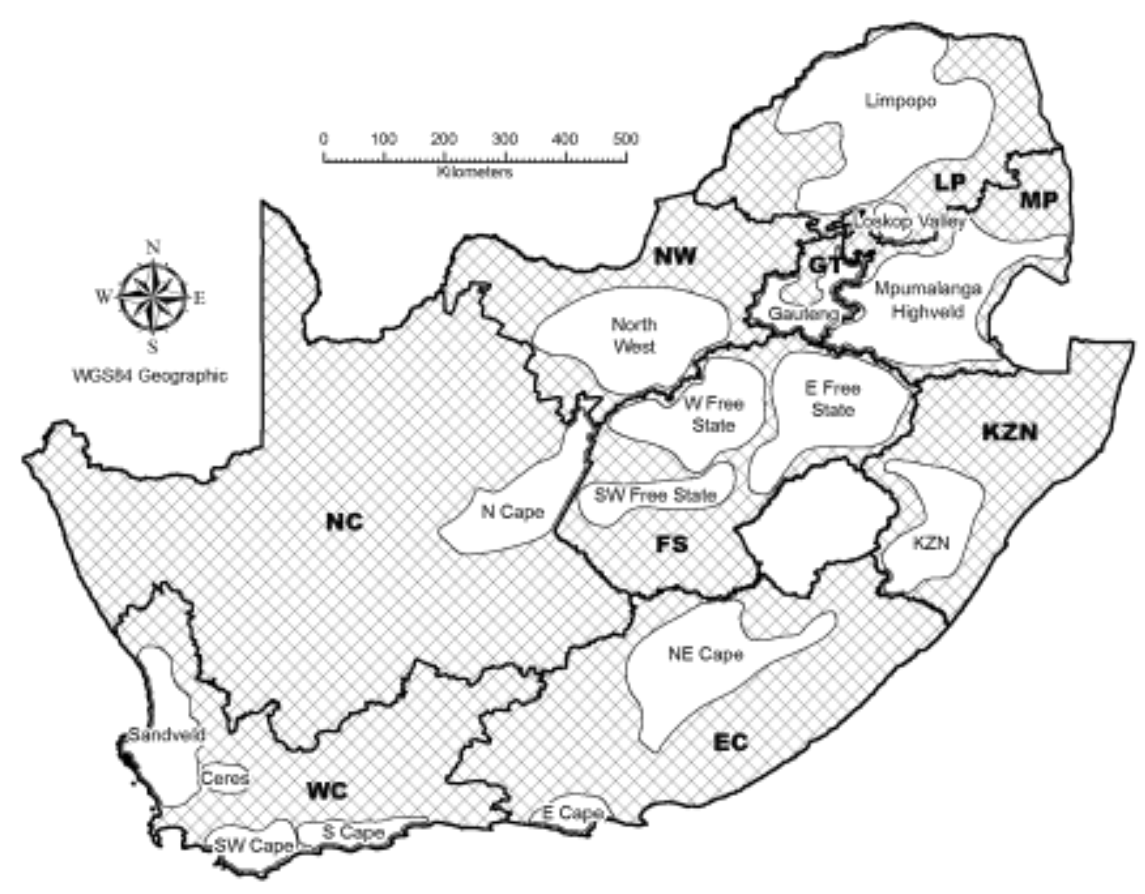

Fig. 1. Map indicating the approximate positions of potato production regions in South Africa. EC = Eastern Cape; FS = Free State; GT = Gauteng; KZN = KwaZulu-Natal; LP = Limpopo; MP = Mpumalanga; NC = Northern Cape; $\mathrm{WC}=$ Western Cape; NW = North West (adopted from Van der Waals et al., 2016; designed by L. van Zyl, TerraGIS, South Africa).

\section{Methodology}

All 16 potato production regions of South Africa were visited in 2013 and 2014 to conduct surveys on the use of input resources such as land, water, fertilizers, chemicals, energy and seed. Three or more commercial growers per region, depending on the size of the region and diversity of production systems (Table 2), were randomly selected and interviewed. In the South-Western Cape region the number of potato growers has lately declined to the point that only two growers were available for interviewing, and this region was consequently excluded from further analyses. A total of 106 growers were interviewed, thereby covering approximately $17 \%$ of all commercial potato growers in the country (Potatoes South Africa, 2015). The sample included producers of table, seed and processing potatoes, as well as 
dryland and irrigated production (Table 2). Growers were asked approximately one hundred questions regarding the following inputs and outputs (average over the past five years): yields, levels of inputs used such as seed, chemicals and fertilizers, field operations like land preparation and harvesting practices, and off-site transport of seed and manure. Irrigation questions included the amount of water applied per season, depth of water table and horizontal pumping distance between water source and fields.

For each grower, we calculated resource use and use efficiencies of land, water, N, P and K fertilizers, energy, and seed per unit of fresh potato produced. The use efficiencies of inputs such as land, water and fertilizer were expressed as the amount of output produced per unit of input used or applied (e.g. LUE = tonnes of potatoes produced per hectare of cultivated land). However, energy use is often not so easily measured due to the various forms of energy involved, and the need to quantify energy embedded in the inputs used to produce a crop (Hillier et al., 2009). Energy use can also be related to the carbon footprint of any action, expressed as the amount of $\mathrm{CO}_{2}$ equivalents emitted per amount of produce grown (Haverkort and Hillier, 2011). For this study, the Cool Farm Tool-Potato (CFT-Potato) (Hillier et al., 2009; Haverkort and Hillier, 2011) was used to calculate the amount of $\mathrm{CO}_{2}$ equivalents emitted (carbon footprint) as an indicator of input energy needed (Hillier et al., 2009), although other greenhouse gasses such as methane and nitrous oxide, that are not directly related to energy use, also contribute to the carbon footprint. 
Table 1. Agro-ecological conditions during the growing season of potato production regions in South Africa ${ }^{1}$

\begin{tabular}{|c|c|c|c|c|c|c|c|c|c|c|}
\hline \multirow{2}{*}{$\#$} & \multirow{2}{*}{ Region } & \multirow{2}{*}{$\begin{array}{l}\text { Name } \\
\text { abbre- } \\
\text { viation }\end{array}$} & \multirow{2}{*}{$\begin{array}{l}\text { Mean } \\
\text { altitude } \\
(\mathrm{m})\end{array}$} & \multirow{2}{*}{ Growing conditions } & \multirow{2}{*}{$\begin{array}{c}\text { Total } \\
\text { solar } \\
\text { radiation } \\
\left(\mathrm{MJ} \mathrm{m}^{-2}\right)\end{array}$} & \multicolumn{2}{|c|}{$\begin{array}{c}\text { Mean daily } \\
\text { temperature }\left({ }^{\circ} \mathrm{C}\right)^{3}\end{array}$} & \multirow{2}{*}{$\begin{array}{c}\text { Main } \\
\text { planting } \\
\text { month }^{4}\end{array}$} & \multirow{2}{*}{$\begin{array}{c}\text { Total } \\
\text { rainfall }^{5} \\
(\mathrm{~mm})\end{array}$} & \multirow{2}{*}{ Predominant soils } \\
\hline & & & & & & Max & Min & & & \\
\hline 1 & Eastern Free State & EFS & 1700 & Wet summer & 2872 & 24.5 & 11.5 & Sep & 319 & Loam \\
\hline 2 & Limpopo & Lim & 1000 & Dry winter & 2368 & 25.8 & 9.3 & Jun & 37 & Loam \\
\hline 3 & Western Free State & WFS & 1250 & Wet summer & 2588 & 28.4 & 12.1 & Jan & 230 & Sand - sandy loam \\
\hline 4 & Sandveld & Sand & 120 & Wet winter / dry summer & 2219 & 23.3 & 6.3 & Jun & 127 & Sand \\
\hline 5 & KwaZulu-Natal & $\mathrm{KZN}$ & 1400 & Wet summer & 1739 & 24.3 & 12.9 & Aug & 251 & Loam - clay loam \\
\hline 6 & Mpumalanga Highveld & $\mathrm{HV}$ & 1600 & Wet summer & 2442 & 25.2 & 8.2 & Aug & 246 & Sandy loam \\
\hline 7 & North West & NW & 1350 & Wet summer & 2621 & 28.7 & 9.4 & Aug & 127 & Sand \\
\hline 8 & North Eastern Cape & NEC & 1300 & Wet summer & 2125 & 21.6 & 9.7 & Sep & 326 & Sandy loam \\
\hline 9 & Northern Cape & $\mathrm{NC}$ & 1050 & Wet summer & 2479 & 28.9 & 13.2 & Jan & 184 & Sandy loam - loam \\
\hline 10 & Eastern Cape & $\mathrm{EC}$ & 50 & Wet summer & 1731 & 22.8 & 9.5 & Jul & 181 & Loam \\
\hline 11 & Loskop Valley & LV & 900 & Wet summer & 1946 & 24.2 & 5.6 & May & 18 & Sandy loam \\
\hline 12 & Ceres & Ceres & 550 & Wet winter & 2140 & 25.1 & 11.1 & Oct & 107 & Sand \\
\hline 13 & South Western Free State & SWFS & 1300 & Wet summer & 2219 & 27.4 & 9.0 & Aug & 142 & Sandy loam \\
\hline 14 & Gauteng & GT & 1580 & Wet summer & 1996 & 23.3 & 7.9 & Jul & 111 & Loam - clay loam \\
\hline 15 & Southern Cape & SC & 220 & Wet summer / winter & 1413 & 19.6 & 8.9 & Jul & 242 & Sandy loam \\
\hline 16 & South Western Cape & SWC & 25 & Wet winter & 1825 & 21.9 & 11.3 & Aug & 406 & Sandy \\
\hline
\end{tabular}

Notes: ${ }^{1}$ Table adopted from Van der Waals et al. (2016), as data for both studies came from the same survey. ${ }^{2}$ Total solar radiation is accumulated incident global radiation $\left(\mathrm{MJ} \mathrm{m}^{-2}\right.$ ) from emergence to maturity; ${ }^{3,5}$ during the growing season; ${ }^{4}$ main period indicated, but some regions have multiple planting times. 
Table 2. Potato production regions in South Africa and their relative contribution to the national production, number of table, processing and seed potato growers interviewed per region*

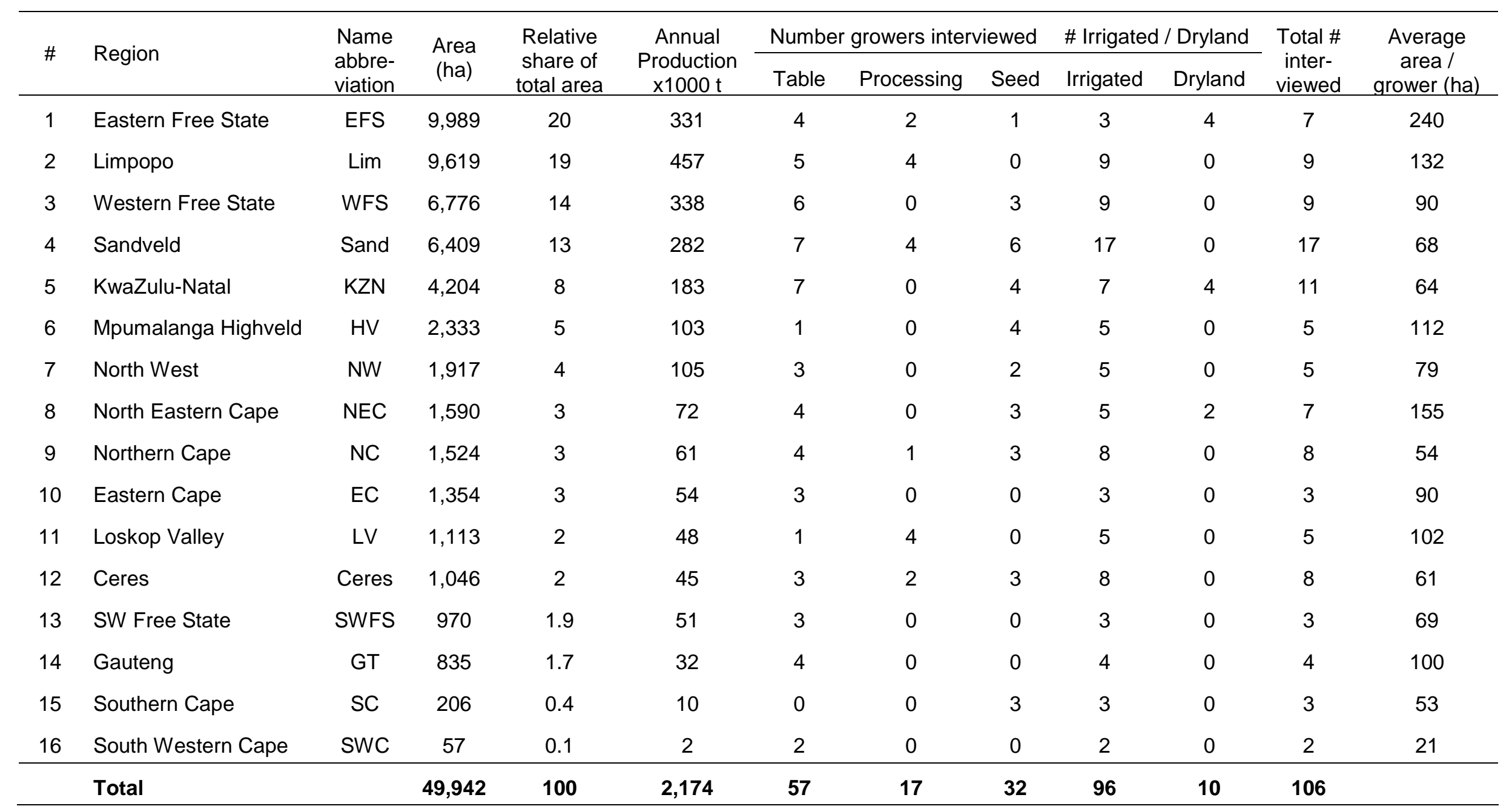

*Note: ${ }^{1}$ Table adapted from Van der Waals et al. (2016), as both studies were conducted during the same survey. 
Yield gap analyses were conducted to assess how actual yields achieved by growers compared with simulated potential yields of each region, following the approach recommended by Van Ittersum et al. (2013). The LINTUL crop growth model (Caldiz et al., 2001; Haverkort et al., 2015; Kooman and Haverkort, 1994) was used to calculate potential potato yields, defined as the theoretical upper yield limit in a situation where water, nutrients and biological factors are not limiting. The LINTUL model has a daily time step and calculates potential yield based on planting and harvest dates, temperature and the amount of solar radiation available, depending on the fraction of radiation intercepted and a temperature and $\mathrm{CO}_{2}$ dependent radiation use efficiency (Haverkort et al., 2015). The yield gap was calculated as the difference between potential yield and actual yield (Haverkort and Struik, 2015; Van Ittersum et al., 2013). LINTUL also calculates potential water use, from which irrigation requirements were calculated. Irrigation need was defined as the difference between the calculated theoretical evapotranspiration (ET) and the average long-term precipitation $(\mathrm{P})$ recorded between planting and harvest, divided by an assumed irrigation efficiency of $75 \%$ (Haverkort et al., 2015). Both potential yields and irrigation requirements were simulated for non-limiting (i.e. full irrigation) conditions. Daily evapotranspiration (ET) was calculated by LINTUL as the product of reference evapotranspiration (ETo, according to Allen et al., 1998) and simulated canopy cover (Franke et al., 2011). The LINTUL model was previously calibrated and successfully used for other potato simulation studies in southern Africa (Franke et al., 2011, Franke et al., 2013, Haverkort et al., 2013, Molahlehi et al., 2013). Observed long-term daily meteorological data (10 - 15 years), including maximum and minimum temperatures, global solar radiation, ETo and rainfall, were obtained from ARC-Institute for Soil Climate and Water weather stations in each region and used as inputs for the model. Water use efficiency (WUE, expressed in $\mathrm{kg} \mathrm{m}^{-3}$ ) was calculated as the fresh tuber yield produced per total amount of rainfall and irrigation applied during the growing season (van Halsema and Vincent, 2012). 
Correlations between parameters were assessed with the Spearman Rank Correlation Test. Statistical analyses were done with Genstat, version 15.1.0. Radar diagrams were constructed to simultaneously allow comparisons of the relative performance of regions for different indicators. A relative scale from $0-100$ was used in the diagrams, where 100 represents the performance of the best region with respect to that specific indicator and values less than 100 indicate performance relative to the best performing region, except for phosphorus use efficiency (PUE), where values were not expressed relative to the best region (Southern Cape), but relative to the second best performing region. For instance, a value of 65 indicates a use efficiency equivalent to $65 \%$ of the best performing region. The PUE of other regions was not compared to the Southern Cape because of the very high PUE values (average $2007 \mathrm{~kg}$ potato / $\mathrm{kg} \mathrm{P}$ ) recorded for this region, compared to the other regions $(147-690 \mathrm{~kg} / \mathrm{kg} \mathrm{P}$ ). As a result, the PUE performance of all other regions as a percentage of the Southern Cape gave very small values, which skewed the diagrams.

\section{Results and Discussion}

Results on resource input levels applied for each region are presented in Table 3, and calculated resource use efficiencies for each region are presented in Table 4.

\subsection{Land}

The land use efficiency (LUE, or fresh tuber yield) averaged across regions was $45 \mathrm{t} \mathrm{ha}^{-1}$, which compares well with the reported national average yield of $43 \mathrm{t} \mathrm{ha}^{-1}$ (Potatoes South Africa, 2015). However, the range in yields between growers within regions is striking (Table 4, ranges in brackets). Highest LUEs were achieved in regions that produce potatoes under irrigation in summer (Mpumalanga Highveld, North West, South-Western Free State and Western Free State), where solar radiation is high, but heat stress is limited due to their midaltitudes (Table 1). The high productivity of these regions corresponds well with the relatively high simulated potential yields (Table 4). Lowest land use efficiencies were reported for the 
predominantly dryland (Eastern Free State) and partially dryland regions (North Eastern Cape and KwaZulu-Natal), where drought stress is common due to unreliable rainfall during the growing season. Yields are also low for the Eastern Cape, where full irrigation is practiced. This can partly be explained by the lower radiation levels in this region, and furthermore probably also by the very short crop rotation cycle practiced in this region (potatoes grown every year to every three years, compared to a typical cycle of once in four to six years for other regions), with high associated disease pressure risk (van der Waals et al., 2016).

Simulated potential LUEs for the different production regions are given in Table 4. Potential yields are usually not achieved commercially (Van Ittersum and Rabbinge, 1997) as with each additional unit of input added beyond the economical optimum, the crop will benefit less and growers will therefore stop applying inputs when it cost more than it yields in monetary terms (Haverkort and Struik, 2015). The difference between potential and actual yields is referred to as the yield gap (Van Ittersum and Rabbinge, 1997; Van Ittersum et al., 2013). This can also be expressed as the ratio of actual yield to potential yield, which illustrates how successful growers are in making best use of their environment and available resources to attain high yields (Lu et al., 2003). Actual:potential LUE ratios exceeded $60 \%$ for most regions (Table 4). Ceres, Gauteng, Mpumalanga Highveld and especially the Southern Cape have relatively small yield gaps, suggesting that the available environment is being efficiently utilised and there is limited scope to further increase yields in these regions.

Substantial yield gaps were evident in regions with dryland cropping, e.g. the Eastern Free State, which has highest yield potential due to high total seasonal solar radiation and moderate air temperatures (Table 1), but lowest actual yields of all regions. However, some irrigated regions also showed large yield gaps, e.g. the Sandveld region only attains $55 \%$ of its potential, suggesting that the available environment and input resources are not being optimally utilised. This could be due to insufficient input levels, or the inefficient use of inputs resources applied, with room for improved practices. 
Table 3. Average resource input levels for potato production regions in South Africa. Values in brackets represent the minimum and maximum input values recorded in each region

\begin{tabular}{|c|c|c|c|c|c|c|c|c|}
\hline Region $^{1}$ & $\begin{array}{c}\text { Actual } \\
\text { irrigation } \\
\text { amount }(\mathrm{mm})\end{array}$ & $\begin{array}{l}\text { Calculated } \\
\text { irrigation } \\
\text { need }(\mathrm{mm})\end{array}$ & $\begin{array}{c}\text { Manure / } \\
\text { compost (t/ha) }\end{array}$ & $\begin{array}{l}\text { Total N² } \\
(\mathrm{kg} / \mathrm{ha})\end{array}$ & $\begin{array}{l}\text { Total } P^{2} \\
(\mathrm{~kg} / \mathrm{ha})\end{array}$ & $\begin{array}{l}\text { Total K² } \\
\text { (kg/ha) }\end{array}$ & $\begin{array}{c}\text { Seed } \\
\text { rate (t/ha) }\end{array}$ & $\begin{array}{l}\text { Energy use } 3 \\
\left(\text { t CO}_{2} / \text { ha) }\right.\end{array}$ \\
\hline \multirow[t]{2}{*}{ EFS } & 121 & 271 & 0.6 & 142 & 75 & 123 & 1.6 & 4.1 \\
\hline & $(0-450)$ & & $(0-4.0)$ & $(100-260)$ & $(45-110)$ & $(60-260)$ & $(0.9-4.0)$ & $(2.4-7.7)$ \\
\hline \multirow[t]{2}{*}{ EC } & 393 & 263 & 0.9 & 218 & 96 & 96 & 3.9 & 7.2 \\
\hline & $(300-480)$ & & $(0-1.8)$ & $(160-293)$ & $(83-105)$ & $(70-118)$ & $(3.3-4.4)$ & (6.2-8.2) \\
\hline \multirow[t]{2}{*}{ NEC } & 228 & 132 & 0.0 & 256 & 112 & 221 & 3.9 & 6.9 \\
\hline & $(45-400)$ & & & $(200-300)$ & $(60-160)$ & $(140-300)$ & $(3.0-5.0)$ & $(5.3-8.2)$ \\
\hline \multirow[t]{2}{*}{$\mathrm{KZN}$} & 263 & 115 & 0.0 & 163 & 145 & 239 & 3.1 & 6.7 \\
\hline & $(0-500)$ & & & $(80-300)$ & $(105-200)$ & $(140-300)$ & $(1.7-5.0)$ & $4.8-10.4$ \\
\hline \multirow[t]{2}{*}{ LV } & 475 & 292 & 0.0 & 212 & 84 & 206 & 3.7 & 7.3 \\
\hline & $(300-800)$ & & & $(190-240)$ & $(70-100)$ & $(190-230)$ & $(3.3-4.3)$ & $(6.7-8.6)$ \\
\hline \multirow[t]{2}{*}{$\mathrm{NC}$} & 400 & 303 & 1.9 & 249 & 104 & 193 & 4.1 & 7.3 \\
\hline & $(350-500)$ & & $(0-15)$ & $(200-390)$ & $(55-165)$ & $(85-410)$ & $(3.0-6.9)$ & $(5.6-10.4)$ \\
\hline \multirow[t]{2}{*}{ SC } & 250 & 146 & 2.3 & 132 & 36 & 149 & 2.2 & 7.4 \\
\hline & $(200-300)$ & & $(0-4.0)$ & $(110-166)$ & $(12-70)$ & $(120-180)$ & $(0.5-3.0)$ & $(5.6-8.8)$ \\
\hline \multirow[t]{2}{*}{ GT } & 513 & 279 & 16.3 & 368 & 381 & 510 & 3.5 & 14.0 \\
\hline & $(300-800)$ & & $(0.1-65)$ & $(201-600)$ & $(210-485)$ & $(350-750)$ & $(2.5-4.3)$ & $(7.4-17.4)$ \\
\hline \multirow[t]{2}{*}{ Sand } & 604 & 380 & 0.0 & 310 & 169 & 453 & 3.6 & 15.0 \\
\hline & $(280-880)$ & & & $(255-344)$ & $(125-200)$ & $(400-550)$ & $(3.0-4.5)$ & $(10.5-24.6)$ \\
\hline \multirow[t]{2}{*}{ Lim } & 454 & 445 & 1.0 & 257 & 103 & 203 & 4.5 & 10.8 \\
\hline & $(360-800)$ & & $(0-5.0)$ & $(220-320)$ & $(30-200)$ & $(140-285)$ & $(3.3-5.0)$ & $(6.8-14.4)$ \\
\hline \multirow[t]{2}{*}{ Ceres } & 774 & 321 & 1.0 & 373 & 117 & 431 & 4.3 & 14.0 \\
\hline & $(600-900)$ & & $(0-2.0)$ & $(300-400)$ & $(100-175)$ & $(350-480)$ & $(3.8-5.3)$ & $(11.1-18.7)$ \\
\hline \multirow[t]{2}{*}{ WFS } & 421 & 298 & 0.0 & 254 & 136 & 188 & 3.9 & 9.9 \\
\hline & $(350-700)$ & & & $(120-320)$ & $(78-240)$ & $(89-300)$ & $(1.5-5.5)$ & $(4.0-17.0)$ \\
\hline \multirow[t]{2}{*}{ SWFS } & 550 & 516 & 0.0 & 253 & 136 & 126 & 3.3 & 8.9 \\
\hline & $450-700)$ & & & $(230-280)$ & $(115-154)$ & $(114-150)$ & $(3.1-3.5)$ & $(8.2-9.4)$ \\
\hline \multirow[t]{2}{*}{ NW } & 440 & 382 & 0.2 & 321 & 214 & 335 & 4.1 & 11.1 \\
\hline & $(300-650)$ & & $(0-1.0)$ & $(290-360)$ & $(150-260)$ & $(300-390)$ & $(3.0-7.5)$ & $(9.1-14.8)$ \\
\hline \multirow[t]{2}{*}{ HV } & 270 & 240 & 0.0 & 228 & 90 & 263 & 3.6 & 8.0 \\
\hline & $(200-400)$ & & & $(200-250)$ & $(80-120)$ & (220-293) & $(2.4-5.0)$ & $(6.3-9.4)$ \\
\hline $\begin{array}{c}\text { Overall } \\
\text { Average }\end{array}$ & 427 & 242 & 1.1 & 255 & 134 & 273 & 3.6 & 9.8 \\
\hline
\end{tabular}

${ }^{1}$ See Table 1 for abbreviation of region names; ${ }^{2}$ Total from organic and inorganic sources; ${ }^{3}$ Energy use is expressed as tonne $\mathrm{CO}_{2}$ equivalents emitted per hectare 
Table 4. Average resource use efficiencies, potential Land Use Efficiency (LUE) and ratio of actual to potential Land Use Efficiency (LUE) per region. Numbers in brackets represent the minimum and maximum values recorded in the region. Resource use efficiencies expressed as amount of fresh tuber yield per amount of input used

\begin{tabular}{|c|c|c|c|c|c|c|c|c|c|}
\hline Region $^{1}$ & $\begin{array}{l}\mathrm{LUE}^{2} \\
(\mathrm{t} / \mathrm{ha})\end{array}$ & $\begin{array}{l}\text { Potential } \\
\text { LUE } \\
\text { (t/ha) }\end{array}$ & $\begin{array}{l}\text { Actual: } \\
\text { potential } \\
\text { LUE(t/ha) }\end{array}$ & $\begin{array}{l}\text { WUE }^{3} \\
\left(\mathrm{~kg} / \mathrm{m}^{3}\right)\end{array}$ & $\begin{array}{c}\mathrm{NUE}^{4} \\
(\mathrm{~kg} / \mathrm{kg} \mathrm{N})\end{array}$ & $\begin{array}{c}\text { PUE }^{5} \\
(\mathrm{~kg} / \mathrm{kg} \mathrm{P})\end{array}$ & $\begin{array}{c}\mathrm{KUE}^{6} \\
(\mathrm{~kg} / \mathrm{kg} \mathrm{K})\end{array}$ & $\begin{array}{c}\text { SUE }^{7} \\
\text { (t/t seed) }\end{array}$ & $\begin{array}{c}\mathrm{EUE}^{8} \\
\left.(\mathrm{~kg} / \mathrm{kg} \mathrm{CO})_{2}\right)\end{array}$ \\
\hline \multirow{2}{*}{ EFS } & 27.7 & \multirow{2}{*}{106.9} & \multirow{2}{*}{0.26} & 7.0 & 210 & 387 & 265 & 20 & 7.04 \\
\hline & $(24-35)$ & & & $(4.2-9.1)$ & $(115-264)$ & (318-533) & $(115-400)$ & $(8.8-28.6)$ & $(3.91-9.80)$ \\
\hline \multirow{2}{*}{ EC } & 39.7 & \multirow{2}{*}{64.9} & \multirow{2}{*}{0.61} & 7.0 & 194 & 418 & 435 & 10 & 6.58 \\
\hline & $(28-41)$ & & & $(6.2-8.3)$ & $(137-235)$ & $(380-494)$ & $(339-586)$ & $(9.4-11.7)$ & $(3.91-5.52)$ \\
\hline \multirow{2}{*}{ NEC } & 41.4 & \multirow{2}{*}{74.7} & \multirow{2}{*}{0.55} & 7.8 & 165 & 414 & 205 & 10.8 & 6.00 \\
\hline & $(38-50)$ & & & $(5.5-11.6)$ & $(133-200)$ & $(238-650)$ & $(127-307)$ & $(8.6-14.3)$ & $(5.08-7.52)$ \\
\hline \multirow{2}{*}{ KZN } & 41.8 & \multirow{2}{*}{64.8} & \multirow{2}{*}{0.65} & 9.1 & 310 & 300 & 186 & 14.9 & 6.14 \\
\hline & $(33-52)$ & & & (5.3-14.8) & $(167-563)$ & $(200-476)$ & 132-357) & (8.3-23.5) & $(3.82-10.2)$ \\
\hline \multirow{2}{*}{ LV } & 43.2 & \multirow{2}{*}{63.2} & \multirow{2}{*}{0.68} & 9.9 & 205 & 524 & 211 & 11.8 & 5.95 \\
\hline & $(40-45)$ & & & $(5.5-13.5)$ & $(182-237)$ & $(400-643)$ & $(196-237)$ & $(9.4-13.8)$ & $(5.26-6.45)$ \\
\hline \multirow{2}{*}{ NC } & 44.8 & \multirow{2}{*}{72.7} & \multirow{2}{*}{0.62} & 8.0 & 183 & 487 & 278 & 12.6 & 5.86 \\
\hline & $(38-70)$ & & & $(6.0-14.9)$ & $(123-250)$ & $(291-714)$ & $(117-447)$ & $(5.5-23.3)$ & $(4.44-10.0)$ \\
\hline \multirow{2}{*}{ SC } & 45.7 & \multirow{2}{*}{54.1} & \multirow{2}{*}{0.84} & 9.3 & 361 & 2007 & 131 & 14.5 & 6.06 \\
\hline & $(42-50)$ & & & (8.3-10.2) & $(253-455)$ & $(714-3750)$ & $(278-375)$ & $(14-15)$ & (5.10-8.93) \\
\hline \multirow{2}{*}{ GT } & 48.1 & \multirow{2}{*}{65.8} & \multirow{2}{*}{0.73} & 8.6 & 149 & 147 & 105 & 14.9 & 3.25 \\
\hline & $(40-60)$ & & & $(5.5-14.6)$ & $(71-199)$ & $(88-286)$ & $(57-171)$ & $(9.4-24.0)$ & $(2.53-8.13)$ \\
\hline \multirow[t]{2}{*}{ Sand } & 49.2 & \multirow{2}{*}{90.1} & \multirow{2}{*}{0.55} & 7.8 & 160 & 194 & 110 & 13.9 & 3.24 \\
\hline & $(42-56)$ & & & $(4.6-16.2)$ & $(131-187)$ & $(250-373)$ & $(82-138)$ & $(11.3-18.7)$ & $(1.83-5.21)$ \\
\hline \multirow{2}{*}{ Lim } & 51.6 & 83.6 & 062 & 11.1 & 202 & 665 & 274 & 11.8 & 4.74 \\
\hline & $(40-60)$ & & & (7.2-15.7) & $(180-250)$ & (265-1833) & $(167-429)$ & $(8.4-16.9)$ & (3.28-6.71) \\
\hline Ceres & 55.2 & 73.7 & 0.75 & 6.4 & 151 & 475 & 129 & 12.7 & 3.85 \\
\hline & $(45-80)$ & & & $(4.5-9.3)$ & $(115-220)$ & $(431-660)$ & $(106-189)$ & $(10.5-16.0)$ & $(2.67-5.62)$ \\
\hline WFS & 57.1 & 80.2 & & 8.8 & 245 & 491 & 351 & 16.8 & 5.84 \\
\hline & $(45-66)$ & & & $(6.3-11.1)$ & $(166-375)$ & $(242-846)$ & $(193-742)$ & $(10.5-30)$ & $(3.52-11.11)$ \\
\hline SWFS & 58.0 & 91.2 & 0.64 & 8.7 & 229 & 427 & 465 & 17.6 & 6.41 \\
\hline & $(51-63)$ & & & $(6.1-10.1)$ & $(222-240)$ & $(409-443)$ & $(400-553)$ & $(15.7-19.2)$ & $(5.41-7.35)$ \\
\hline NW & 58.2 & 82.9 & 0.70 & 10.5 & 182 & 281 & 173 & 15.9 & 5.23 \\
\hline & $(45-70)$ & & & $(9.0-12.9)$ & $(132-197)$ & $(225-407)$ & $(150-179)$ & $(8.0-20.3)$ & $(4.42-6.76)$ \\
\hline $\mathrm{HV}$ & 60.7 & 83.9 & 0.72 & 12.2 & 271 & 690 & 238 & 18.0 & 7.48 \\
\hline & $(47-67)$ & & & $(7.3-15.0)$ & (188-335) & $(500-838)$ & $(160-305)$ & (13.4-24.9) & $(5.85-10.64)$ \\
\hline $\begin{array}{c}\text { Overall } \\
\text { Average }\end{array}$ & 45 & 78.9 & 0.60 & 8.7 & 209 & 467 & 224 & 14.3 & 5.67 \\
\hline
\end{tabular}

${ }^{1}$ See Table 1 for abbreviations of regions; ${ }^{2} \mathrm{LUE}=$ land use efficiency, ${ }^{3} \mathrm{WUE}=$ water use efficiency, ${ }^{4} \mathrm{NUE}$ $=$ nitrogen use efficiency, ${ }^{5} \mathrm{PUE}=$ phosphorus use efficiency, ${ }^{6} \mathrm{KUE}=$ potassium use efficiency, ${ }^{7} \mathrm{SUE}$ $=$ seed use efficiency, ${ }^{8}$ EUE $=$ energy use efficiency 
The production practices and environmental factors that could play a role in limiting LUE in these regions are further deliberated later in the discussion of overall efficiency and sustainability of production.

All input variables in Table 3 had a significant positive correlation with actual yield, except for input rates of manure / compost, with the strongest correlations between yield and total $\mathrm{N}$, energy input and total irrigation (Table 5). As input variables were in most cases also significantly correlated with each other, except for total solar radiation that did not correlate with other input variables (data not shown), the contribution of individual input factors in the explanation of yield variability was difficult to assess. The results suggest that high yields are achieved by the combined high application rate of different inputs. Figure 2 shows the relationship between total available seasonal solar radiation and actual yield per region. When all regions are included, there was a poor correlation $(r=0.12)$ between accumulated seasonal solar radiation and actual yields recorded. The two outliers in Figure 2 are the Eastern Free State (EFS) and Southern Cape (SC). In the EFS potential yields were high (Table 4) due to high solar radiation and moderate summer air temperatures, which are favourable for potato growth. However, actual yields fell way behind the potential because this is predominantly a dryland production region and yields are limited more by water stress than by available radiation. For the SC region yields are relatively high, given the available radiation. Here, radiation use efficiencies are probably higher due to more cloudy conditions during the growing season (lower available radiation, Table 1), resulting in less saturation of the photosystem. This region is also generally efficient in the use of other resources (nutrients, water) and as a result shows the smallest yield gap. When these two outliers are excluded, the correlation between available radiation and actual yield becomes significant $(r$ $=0.6$, confirming that differences in yield between regions is quite well explained by variability in available solar radiation.

Although commercial growers generally follow appropriate pest and disease control programmes, regions can differ substantially in pest and disease pressure. Variability in crop 
yields, and therefore also resource use efficiencies, may thus be highly dependent on the severity of pest and disease incidence. As part of our survey growers were also questioned about their perceptions of the most important biotic and abiotic risks in each region. These results are, however, not presented in detail here and were published in a separate paper (van der Waals et al., 2015).

Table 5. Correlation between input variables and potato yields per farm in various production regions of South Africa.

\begin{tabular}{lcc}
\hline Input & Correlation coefficient & $\mathrm{t} \mathrm{pr}$ \\
\hline Total radiation & 0.216 & 0.028 \\
Actual irrigation & 0.319 & 0.001 \\
Manure / compost & -0.040 & $\mathrm{n} . \mathrm{s}$. \\
Total N & 0.478 & 0.000 \\
Total P & 0.245 & 0.012 \\
Total K & 0.296 & 0.002 \\
Seed & 0.268 & 0.006 \\
Energy & 0.455 & 0.000 \\
\hline
\end{tabular}

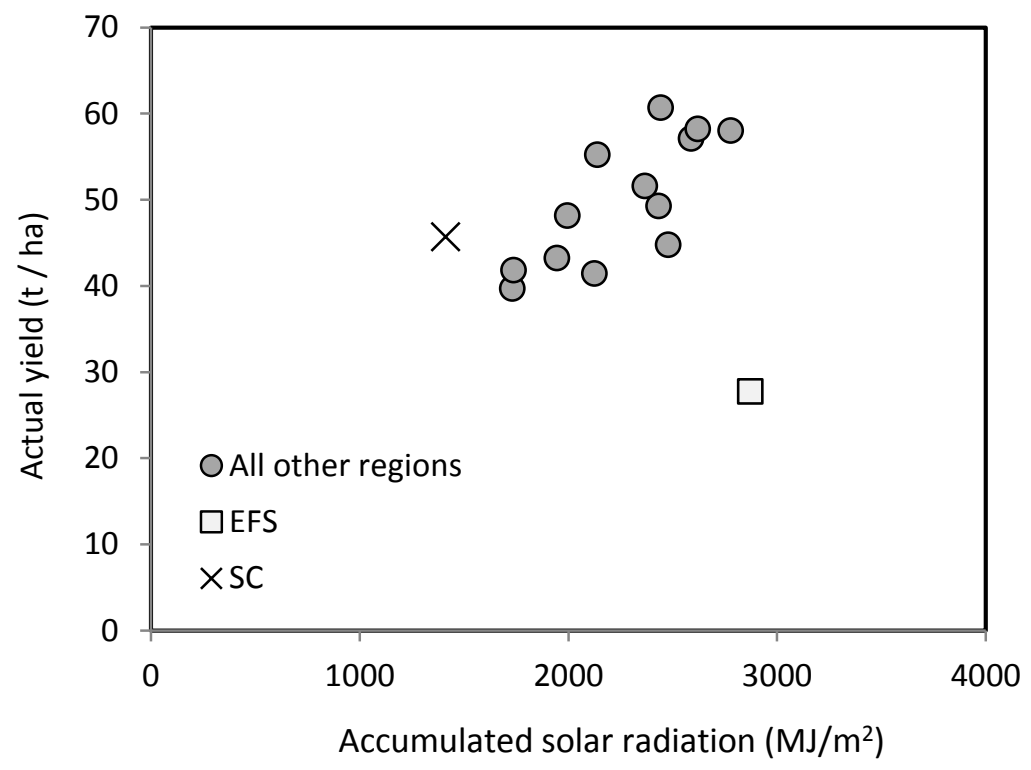

Figure 2. Correlation between cumulative solar radiation and average actual potato yields in various regions of South Africa. The correlation coefficient $(r)$ is 0.12 for all regions, and 0.60 if Southern Cape (SC) and Eastern Free State (EFS) are excluded. 


\subsection{Water}

The potato crop is sensitive to water stress and therefore the amount of water available, compared to what is needed, is regarded an important yield determining factor in any agroecological environment (Onder et al., 2005; Steyn et al., 1998). In our study, crop water use was regarded as the sum of total rainfall during the growing season (from long-term weather data) and irrigation water applied (from grower surveys). Table 3 shows the average actual irrigation amounts (with ranges in brackets) applied by growers and the simulated irrigation needs per region, based on long-term ETo, seasonal rainfall and crop water requirements. Irrigation amounts applied by growers ranged widely, from an average of $121 \mathrm{~mm}$ in the Eastern Free State (mainly dryland) to $774 \mathrm{~mm}$ in Ceres. A good agreement between actual irrigation amounts and calculated irrigation needs existed in only four regions. In all other regions with full irrigation available, the actual irrigation amounts applied exceed calculated irrigation needs by far. The scatter in the data may partly be explained by the erratic nature of rainfall in the summer rainfall regions of South Africa (Mason and Jury, 1997; Tyson, 1986), which can interfere with irrigation management and result in drainage losses. However, it was evident from the surveys that many growers do not appropriately use irrigation scheduling tools to determine crop water needs, resulting in regular over irrigation and wastage of water. This suggests that in several regions improvements in irrigation management could save irrigation water and the energy required to pump water (a major contributor to total on-farm energy use), and improve water use efficiency (WUE).

Regions with the closest agreement between irrigation needs and actual irrigation amounts also had the highest WUE (Table 4). Lowest WUE was recorded for Ceres $\left(6.2 \mathrm{~kg} \mathrm{~m}^{-3}\right)$, where high yields were achieved at high irrigation cost, as the irrigated amounts exceeded the need by more than double. Highest average WUE $\left(11.7 \mathrm{~kg} \mathrm{~m}^{-3}\right)$ was achieved for Mpumalanga Highveld, while the average WUE across all production regions was $8.0 \mathrm{~kg} \mathrm{~m}^{-3}$. This compares well with values reported for studies in Europe and the Mediterranean region (range of $3-15 \mathrm{~kg} \mathrm{~m}^{-3}$ with typical values around $7 \mathrm{~kg} \mathrm{~m}^{-3}$; Ati et al., 2012; Badr et al., 2012; 
Darwish, 2006; Ferreira and Goncalves, 2007; Magliulo, 2003; Molden et al., 2010; Onder et al., 2005). Nevertheless, large variation within and between regions suggests that there is substantial scope for improvement in management by some growers and regions as a whole.

\subsection{Nutrients}

The total amount of nutrients (N, P and $\mathrm{K}$ ) applied to potato differed greatly between and within regions in South Africa (Table 3, ranges in brackets). By far the highest total fertilizer rates were applied in Gauteng (well over $1200 \mathrm{~kg} \mathrm{NPK} \mathrm{ha}^{-1}$ ) and the lowest in the Southern Cape, where the focus on seed potato production is associated with lower (about $350 \mathrm{~kg}$ NPK ha ${ }^{-1}$ ) nutrient input rates (Hoffman and Salomez, 2000). Moreover, in this region potatoes are grown in rotation with pastures for dairy farming. These pastures are fertilised with nutrient-rich effluents from dairy parlours and when the fields are ploughed, organic matter in the sod mineralises and becomes available to the successive potato crop

The fertilizer rates reported in the present study are higher than those typically used in European countries. For example, Vos (2009) reported that in north-western Europe the economical optimal point of $\mathrm{N}$ input is commonly in the range of $150-250 \mathrm{~kg} \mathrm{ha}^{-1}$. Haverkort and Hillier (2011) also reported substantially lower total inorganic NPK application rates, ranging from 117 to $392 \mathrm{~kg} \mathrm{ha}^{-1}$ for different production systems (table, seed, starch) in the Netherlands. However, substantial amounts of manure and slurry are in most cases also applied to potato fields in the Netherlands, although manure is often not applied in the same cropping season as potatoes. In Chile, a large variation in the amount of fertilizers applied by growers was also found, ranging from 295 to $1010 \mathrm{~kg} \mathrm{ha}^{-1}$ NPK (Haverkort et al., 2014). In the present study, the $\mathrm{K}$ fertilizer rates showed the widest nutrient range between regions (from $96 \mathrm{~kg} \mathrm{ha}^{-1}$ for Eastern Cape to $510 \mathrm{~kg} \mathrm{ha}^{-1}$ for Gauteng), followed by N (from $132 \mathrm{~kg}$ $\mathrm{ha}^{-1}$ for Southern Cape to $368 \mathrm{~kg} \mathrm{ha}^{-1}$ for Gauteng) (Table 3). Svubure et al. (2015) found a 
similar wide range in fertilizer rates among potato growers in Zimbabwe: 94 to $272 \mathrm{~kg} \mathrm{ha}^{-1} \mathrm{~N}$, 40 to $160 \mathrm{~kg} \mathrm{ha}^{-1} \mathrm{P}$ and 75 to $329 \mathrm{~kg} \mathrm{ha}^{-1} \mathrm{~K}$.

The large variation in tuber yields and applied nutrient levels per region resulted in a wide range of nutrient use efficiencies (Table 4). High nutrient levels often did not coincide with high yields, resulting in low nutrient use efficiencies. Nitrogen use efficiencies (NUE) ranged widely, from 149 to $361 \mathrm{~kg}$ fresh potato yield (FY) $\mathrm{kg}^{-1} \mathrm{~N}$ applied. These values are in the same range as those reported for studies in the USA (Zotarelli et al., 2015: 58 - $225 \mathrm{~kg}$ potato $\mathrm{FY} \mathrm{kg}{ }^{-1} \mathrm{~N}$ - recalculated from dry matter yield values, assuming a tuber dry matter (DM) content of $20 \%$ and a harvest index of $75 \%$ ), Germany (247 kg potato $\mathrm{FY} \mathrm{kg}^{-1} \mathrm{~N}$ recalculated from Haase et al., 2007) and Lebanon (Darwish et al., 2006: $72-304 \mathrm{~kg} \mathrm{~kg}^{-1} \mathrm{~N}$, assuming a tuber DM content of $20 \%$ ). However, the NUE values for most regions in South Africa were substantially higher than the range of 97 to $162 \mathrm{~kg}_{\text {potato }} \mathrm{FY} \mathrm{kg}{ }^{-1} \mathrm{~N}$ reported for a survey in neighbouring Zimbabwe (Svubure et al., 2015).

Potassium use efficiencies (KUE) varied even more between regions than NUE, ranging

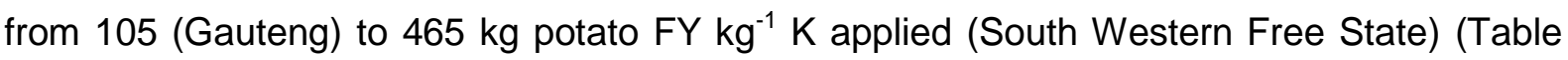
4). These values fall in the same range as those reported for studies in Lebanon (190 - 475 $\mathrm{kg} \mathrm{kg}^{-1}$; Karam et al., 2009), but are substantially higher than those for Germany (162 $\mathrm{kg} \mathrm{kg}^{-1}$ for an inorganic K treatment; Haase et al., 2007). Similar to NUE and KUE, phosphorus use efficiency (PUE) varied widely between regions, from $147 \mathrm{~kg}$ potato $\mathrm{FY} \mathrm{kg}{ }^{-1} \mathrm{P}$ (Gauteng) to a very high $2010 \mathrm{~kg}$ potato $\mathrm{FY} \mathrm{kg}{ }^{-1} \mathrm{P}$ (Southern Cape). This very high PUE value was excluded from the radar diagrams used for overall sustainability assessment (Fig. 5), for reasons discussed later. Phosphorus fertilization rates and PUE are influenced by residual soil P status, especially in soils with substantial residual $P$ levels such as land that has been manured. Although it is common practice in South Africa to take residual soil $P$ status into account when fertilizer programmes are designed, residual soil $\mathrm{P}$ level information was not collected during the survey. PUE values for most regions in this study were lower than the 
$984 \mathrm{~kg} \mathrm{~kg}^{-1} \mathrm{P}$ reported for Germany (calculated from Haase et al., 2007), but similar to the 468 - $737 \mathrm{~kg} \mathrm{~kg}^{-1} \mathrm{P}$ range for the Czech Republic (Šrek et al., 2010).

\subsection{Seed}

Seed comprises the biggest single direct input cost component of potato production in South Africa (van Zyl and van der Westhuizen, 2015) and therefore the efficiency of seed use directly affects the profitability of potato production. Factors that normally affect the amount of seed required to plant a field include seed size, physiological age, the purpose of production (table, processing or seed), and irrigation intensity (Pieterse and Nel, 2012). A substantial variation in the amount of seed planted occurred between and within regions (Table 3), often without obvious justification. The lowest seed rate of $1.64 \mathrm{t} \mathrm{ha}^{-1}$ was reported for the dryland Eastern Free State, a region with low yield potential, followed by Southern Cape $\left(2.2 \mathrm{t} \mathrm{ha}^{-1}\right)$. Higher seed rates were expected for the latter region, since it is exclusively a seed producing area, where the tendency is to plant at high seed densities to ensure a higher proportion of smaller daughter tubers. However, some growers use extremely expensive mini-tubers for the production of high quality seed, and this leads to a lower average seed mass planted per hectare. The Limpopo and Ceres regions have the highest average seed rate of about $4.5 \mathrm{tha}^{-1}$, while for the remaining regions average seed rates varied between 3.1 and $4.1 \mathrm{t} \mathrm{ha}^{-1}$.

Seed use efficiency (SUE or seed multiplication ratio), expressed as fresh tuber yield harvested per tonne of seed planted (Pieterse and Nel, 2012), ranged between 10 and $20 \mathrm{t} \mathrm{t}^{-}$

${ }^{1}$ (Table 4). The low-yielding Eastern Free State dryland production region had the highest SUE $\left(20 \mathrm{t} \mathrm{t}^{-1}\right)$. High seed use efficiencies were also achieved in regions with high fresh tuber yields but moderate seeding rates, such as Mpumalanga Highveld (18 $\left.\mathrm{t} \mathrm{t}^{-1}\right)$ and South Western Free State $\left(17.6 \mathrm{t} \mathrm{t}^{-1}\right)$. Some farmers use rather high seed rates as a risk mitigation strategy, since too low seed rates can be risky under unfavourable climatic conditions, such 
as very hot or wet periods during planting time, posing a risk of seed rotting (van der Waals et al., 2016), leading to a poor plant stand and low yields. Therefore, growers may try to avert risk by planting more seed.

\subsection{Energy}

Total energy use per hectare, ranged from 4.1 to $15 \mathrm{t} \mathrm{CO}_{2}$ eq. ha ${ }^{-1}$ across the production regions evaluated (Table 3). High energy use was not directly related to yields achieved and in some regions with high yields (e.g. Highveld and South Western Free State) farmers had moderate to low energy use. This resulted in a wide range of energy use efficiencies, ranging from a low of $134 \mathrm{~kg} \mathrm{CO}$ eq. $\mathrm{t}^{-1}$ for the Mpumalanga Highveld to $309 \mathrm{~kg} \mathrm{CO}$ eq. $\mathrm{t}^{-1}$ for the Sandveld region (Table 4).

Figure 3 gives a breakdown of the major contributors to total energy use per tonne of potato produced. In almost all regions irrigation and the addition of fertilizer were the major contributors to the energy use ( $\mathrm{CO}_{2}$ emissions), followed by on-farm transport and grading, cooling and storage. In the Netherlands, fertilizer-related emissions contribute by far the most to the $\mathrm{CO}_{2}$ equivalent emissions of potato production, followed by storage and field operations (Haverkort and Hillier, 2011).

In regions where dryland production is practiced (Eastern Free State, North Eastern Cape and KwaZulu-Natal), energy use for irrigation is low and total energy use is also relatively low. The irrigated regions vary substantially in energy use for the pumping of irrigation water. For example, Limpopo and Ceres use more than twice as much energy to pump irrigation water than Mpumalanga Highveld and Loskop Valley. 


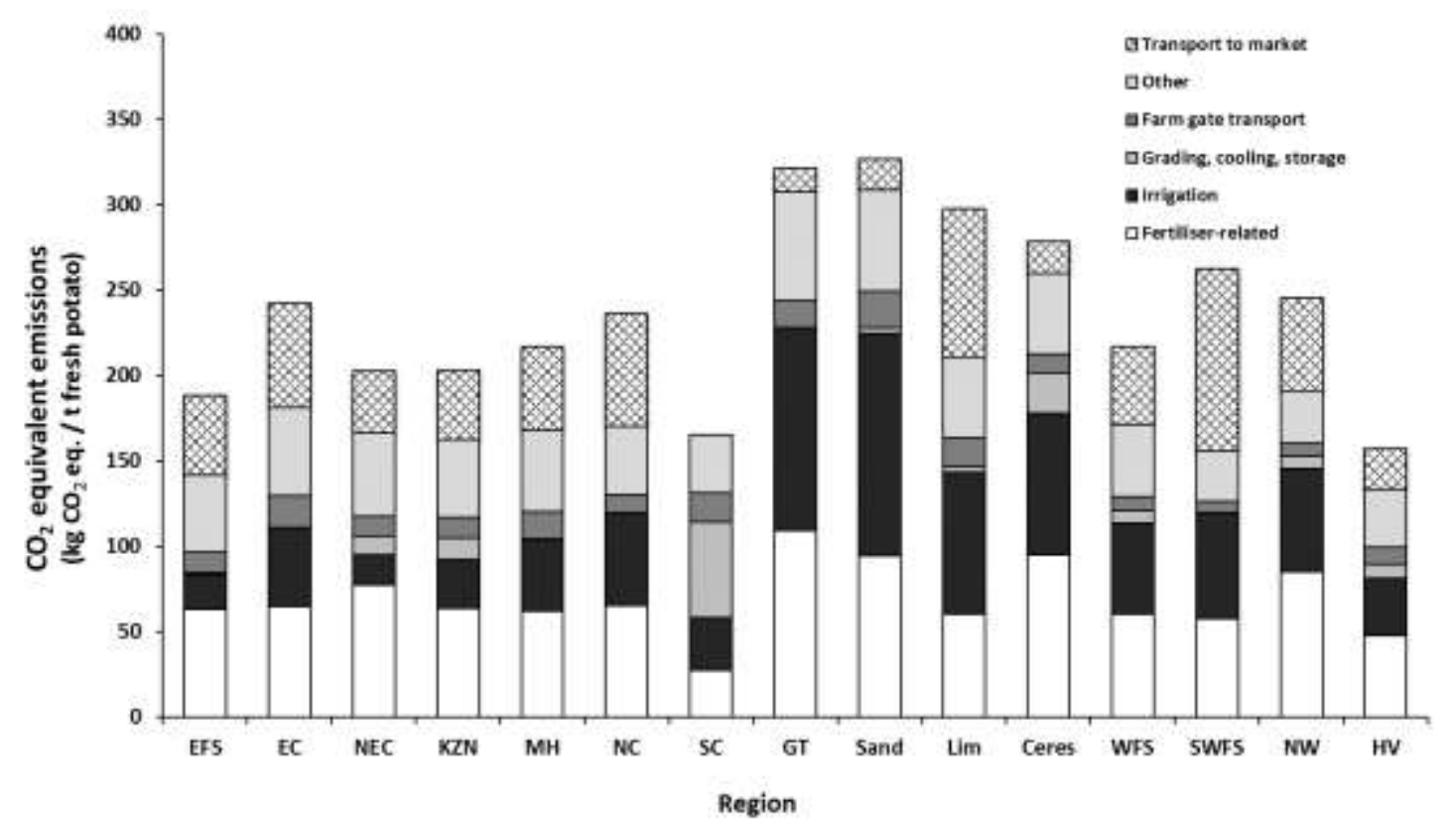

Fig. 3. Major contributors to farm-gate energy use $\left(\mathrm{CO}_{2}\right.$ equivalent emissions) per region (including fertilizers, irrigation, grading, cooling and storage, on-farm transport and other emissions), as well as for transport to the market place (patterned bars) for potato production in different regions of South Africa. See Table 1 for abbreviation of region names.
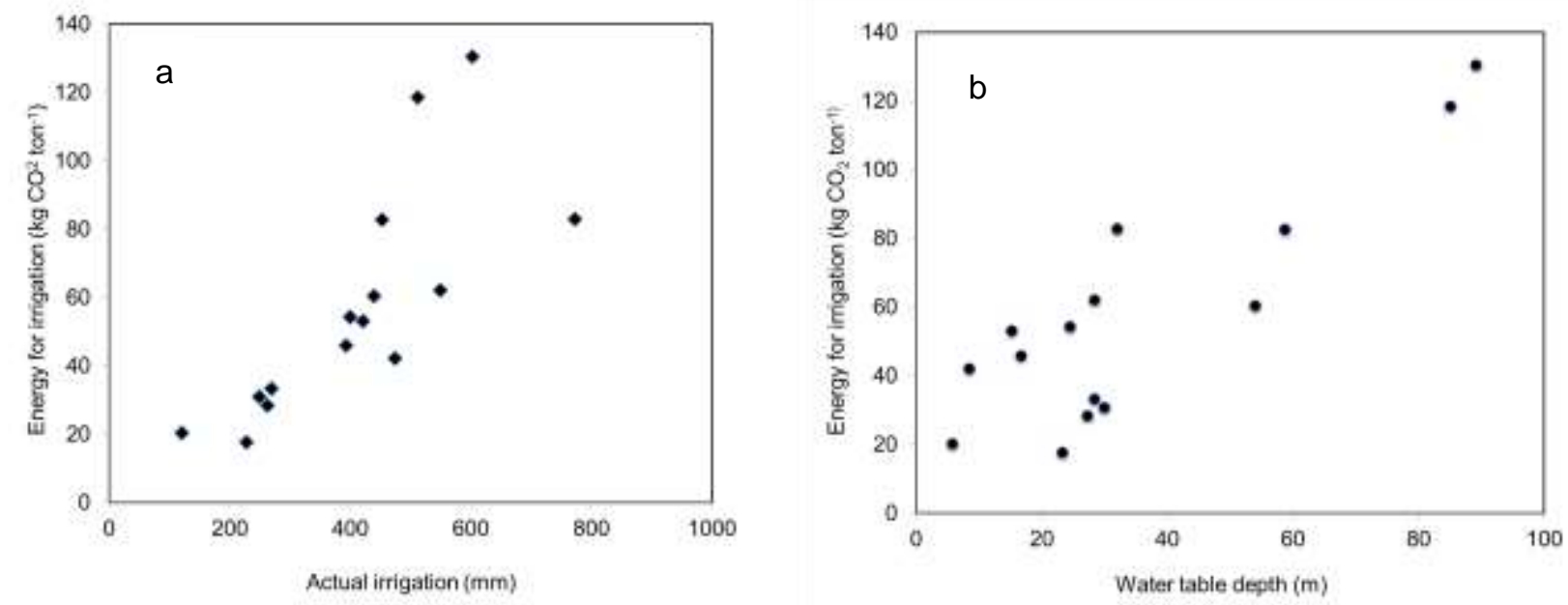

Fig. 4. Scatter plots of average energy needed per region for irrigation versus the (a) actual irrigation amount $(r=0.59)$ and (b) depth of the water table $(r=0.66)$, based on data obtained from the different potato production regions of South Africa 
The amount of energy needed for irrigation correlated well with the amount of irrigation water applied $(r=0.59)$, but also with the depth of the water table from which the irrigation water was retrieved $(r=0.66)$ (Figure 4). The latter relationship is illustrated by the fact that growers in the Limpopo and Ceres regions used the same amount of energy for irrigation (83 $\mathrm{kg} \mathrm{CO}_{2} \mathrm{t}^{-1}$ ), but in Ceres $773 \mathrm{~mm}$ per season is withdrawn from surface reservoirs, compared to only $454 \mathrm{~mm}$ in Limpopo, where water is often pumped over long horizontal distances (up to $2 \mathrm{~km}$ ) from deep boreholes (average depth of $59 \mathrm{~m}$ ).

Fertilizer related energy use was directly related to the amount of NPK nutrients applied and the potato yields achieved. The four regions with highest fertilizer energy use per tonne of potatoes (Gauteng, Ceres, Sandveld and North West) also applied the highest total amounts of NPK (Table 3). Grading, cooling and storage only made a substantial contribution to total energy use in regions where seed potatoes were produced and stored in mechanically cooled storage facilities (Southern Cape, Ceres, KwaZulu-Natal, North Eastern Cape, Western Free State and Mpumalanga Highveld). Of these primary processing activities, cold storage requires by far the most energy. Potatoes for table consumption or processing are usually not cold stored, which explains the low energy requirement for primary processing in the other regions (Figure 3). These potatoes are transported to the different points of sale immediately after harvesting and primary processing, which negates the need for cold storage facilities. However, this practice can result in extreme fluctuations in supply vs. demand, and consequently erratic changes in product prices.

Figure 3 also shows the energy used per region for transporting the harvested potatoes to points of sale (e.g. fresh produce markets). For seed growers there is no energy cost for harvested product transport (e.g. Southern Cape), as that cost is borne by the seed buyer. For fresh market potatoes, regions far away from markets (e.g. Limpopo and South Western Free State) have highest energy need for transport. As a result, total energy use (production plus transport to markets) for these regions increases to similar levels as those of Sandveld, Gauteng and Ceres, which have high energy use because of generally high fertilizer rates 
and irrigation levels. This illustrates that there is a high energy penalty for transport of fresh produce over long distances.
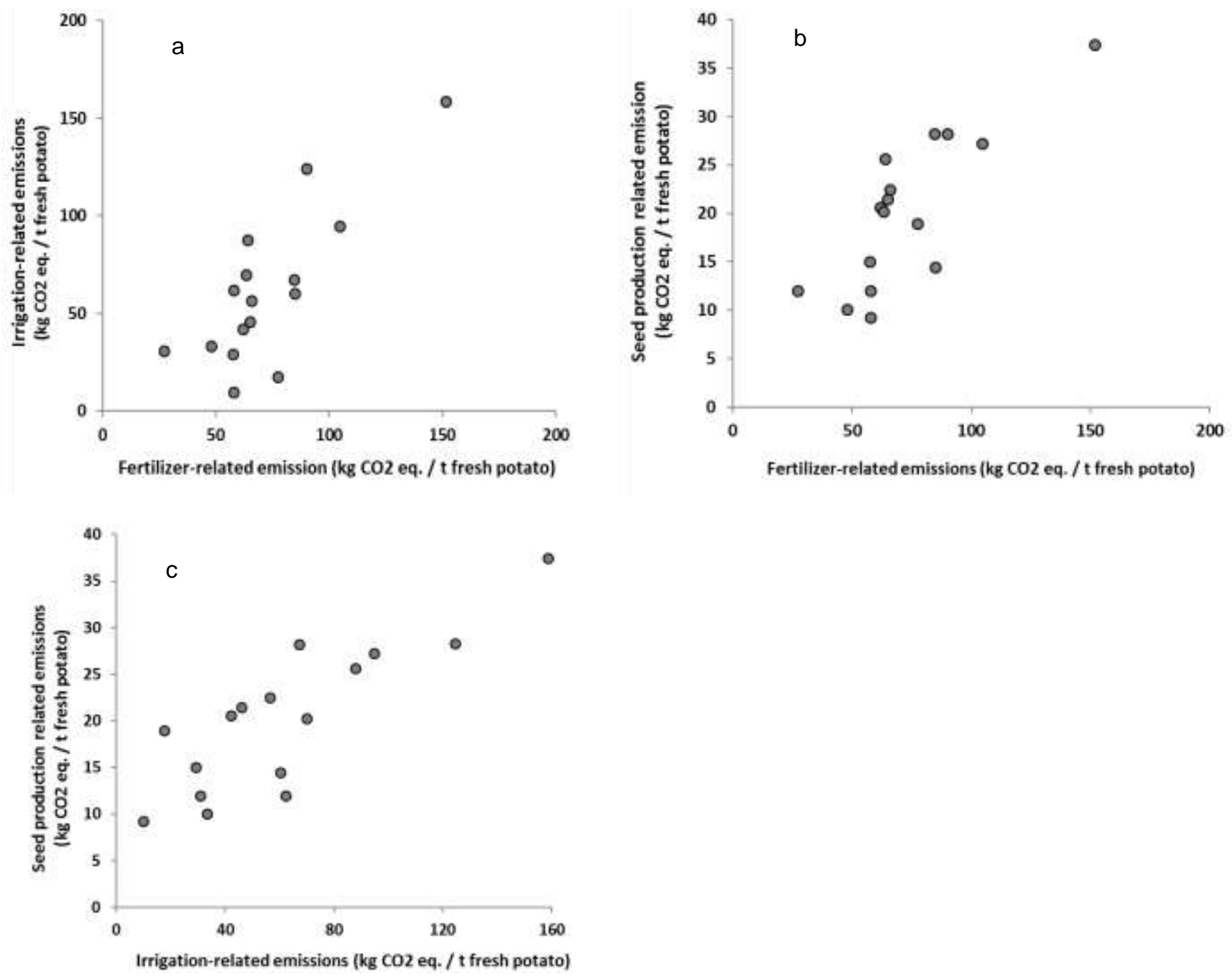

Fig. 5 Relationship between the total energy use $\left(\mathrm{CO}_{2}\right.$ emissions) associated with (a) irrigation and fertilizer $(r=0.665$, t pr $=0.005)$ (b) fertilizer and seed input $(r=0.785$, $\mathrm{pr}<$ $0.00)$ and $(\mathrm{c})$ irrigation and seed input $(r=0.785, \mathrm{t} \mathrm{pr}<0.00)$ for potato production in different regions of South Africa.

There were clear linear relationships between the three main capital and energy intensive aspects of potato production (seed, fertilizer and irrigation) (Figure 5). Increased energy use 
associated with irrigation was positively correlated with the energy use for fertilizer, as an increase in yield expectation from increased irrigation (and higher seeding rates) lead growers to increase their fertilizer application rates. It may also suggest that more irrigation leads to more fertilizer leaching, meaning more fertilizer needs to be applied. Optimizing both should lead to an improvement of one of the others (e.g. more efficient irrigation optimizes efficiency of fertilizer use). Similarly, higher yield expectations from higher fertilizer and irrigation rates are made possible by higher seeding rates. This supports the optimum law of Liebscher, which states that "a production factor which is in minimum supply contributes more to production, the closer other production factors are to their optimum" (De Wit, 1992).

\subsection{Overall efficiency and sustainability of production}

The radar diagrams in Figures $6 \mathrm{a}$ and $6 \mathrm{~b}$ illustrate the overall efficiency or sustainability of potato production for selected regions of South Africa and facilitate comparison of the relative performance of regions regarding their use efficiencies of the most important input resources assessed in this study, i.e. $\mathrm{N}, \mathrm{P}$ and $\mathrm{K}$ nutrients, seed, water and energy use. Regions with high use efficiencies in most resources are characterised by larger shaded areas on the diagrams, while those that are generally inefficient for use of most resources have smaller shaded areas. In these diagrams resources are not weighted in terms of their contribution to sustainability, instead the assumption is that all criteria are of equal importance to overall sustainability (de Vries et al., 2011), which is not necessarily true from an economic point of view. Furthermore, it should be appreciated that the direct comparison in sustainability performance of one region with other regions is not always possible because of differences in biophysical conditions, such as soils and climate. Therefore, not all regions can increase their sustainability performance up to the level of the better performing regions.

The Southern Cape seed producing region generally performed well in most of the efficiency criteria and can be considered the best overall performing region in terms of efficient use of 
available environmental resources. The high irrigation and energy use efficiencies observed for this region can be explained by the fact that rainfall almost meets evapotranspiration and little supplemental irrigation is therefore needed. Mpumalanga Highveld and the Western Free State also achieved good relative resource use efficiencies. For the Eastern Free State intermediate overall sustainability is recorded. Although input levels for this region were generally low, yields were often restricted due to untimely drought, resulting in crop failures and low resource use efficiencies. The shaded areas on the radar diagrams for the Gauteng and Sandveld regions are both small and their shapes almost identical. Nutrient and energy use efficiencies were especially low for both of these regions. In the Sandveld region this is partly explained by the very sandy soils of this region which are difficult to irrigate and have a high risk of nutrient leaching, which necessitates frequent small nutrient applications (in essence a hydroponic production system). The same is not true for Gauteng, where soils are generally loamy in texture. The low nutrient use efficiencies observed for Gauteng mainly stem from over fertilisation. In both regions energy use efficiency is also low, which can mainly be linked to high fertilizer rates and irrigation levels, but only moderate yields. Actual irrigation exceeded irrigation needs substantially in both regions, which suggests overirrigation. In both regions, but especially in the Sandveld, irrigation occurs from deep boreholes and water is pumped over long distances, further contributing to energy use. 
EFS

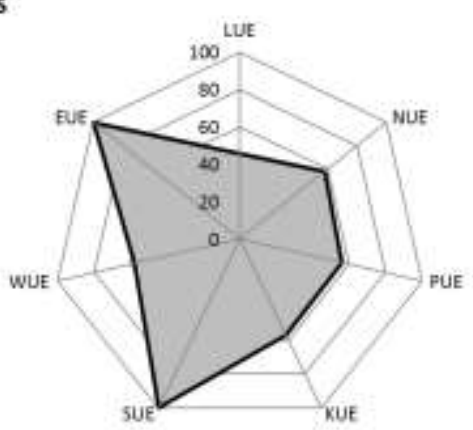

WFS

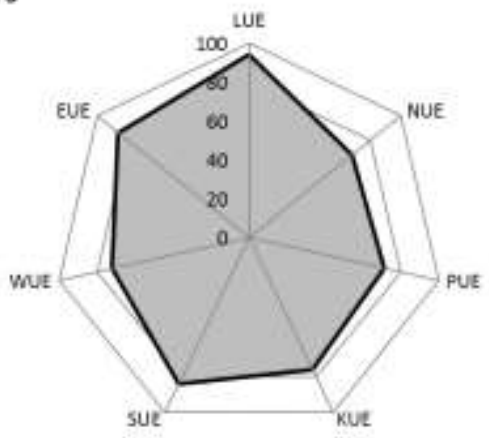

KZN

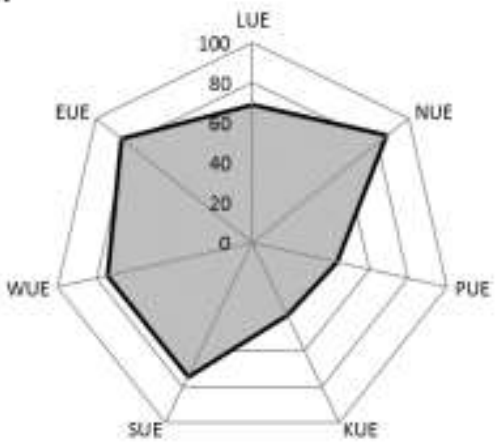

NW

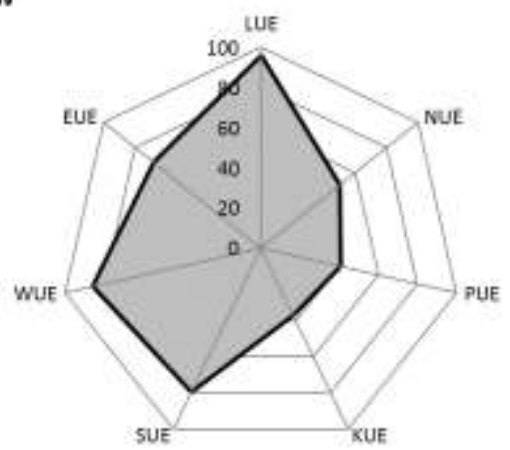

Lim

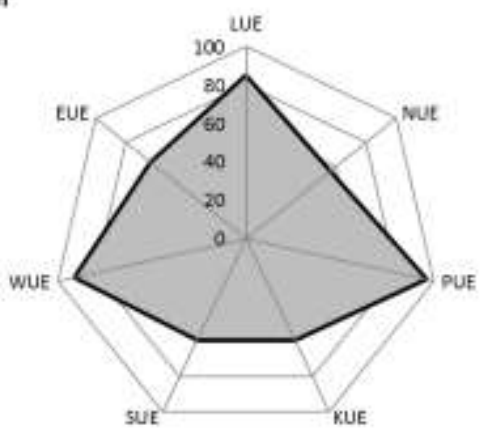

Sand

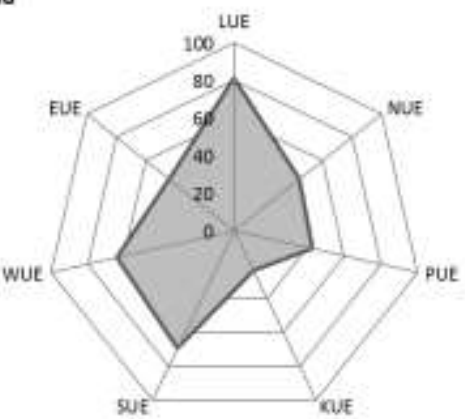

HV

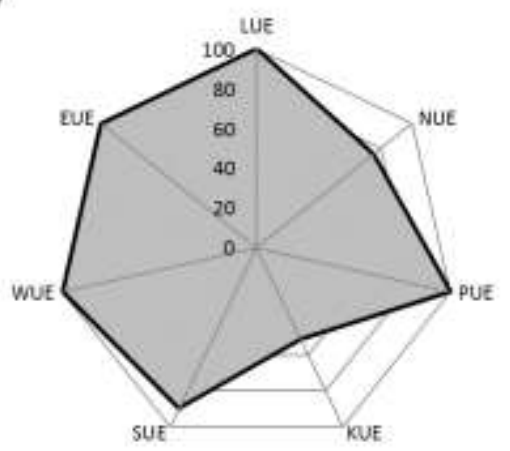

NEC

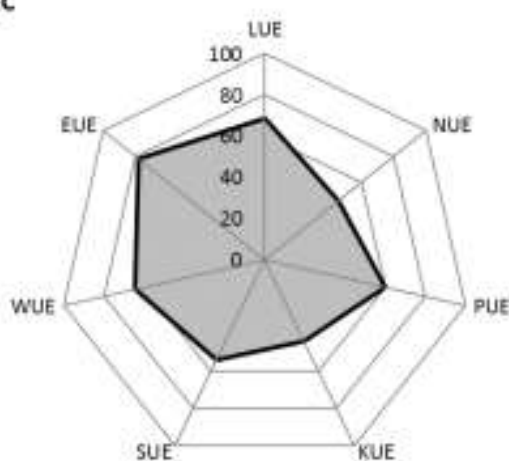

Fig. 6 a: Radar diagrams illustrating the overall sustainability of EFS, Lim, WFS, Sand, KZN, HV, NW and NEC potato production regions in South Africa, based on seven measured resource use efficiencies. Values are in percentages relative to the best performing region (100\%) with respect to each efficiency parameter. The larger the shaded area of a region, the higher the overall efficiency. See Table 2 for abbreviation of region names. 
NC

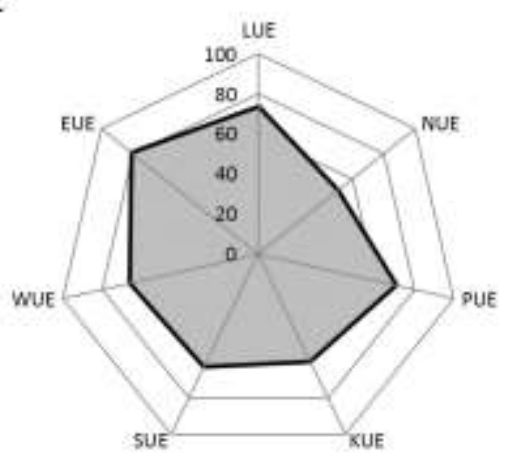

Lv

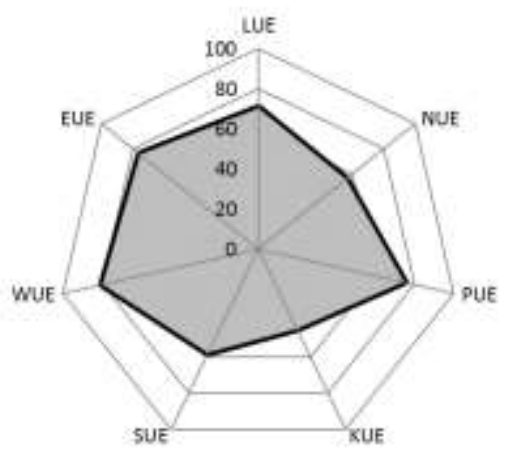

SWFS

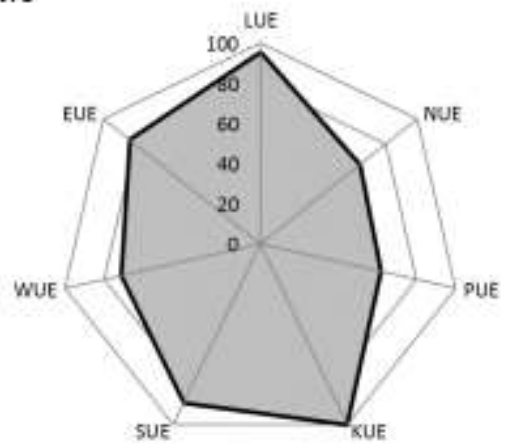

sc

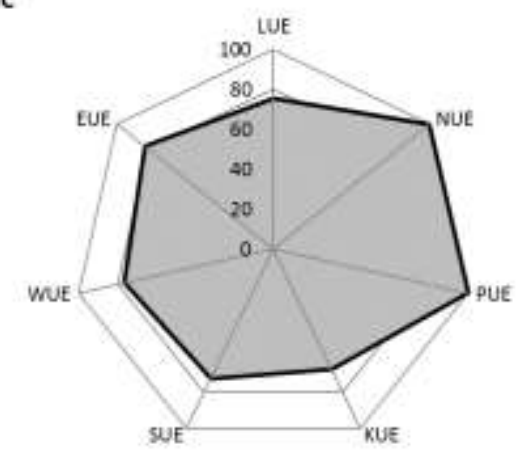

EC

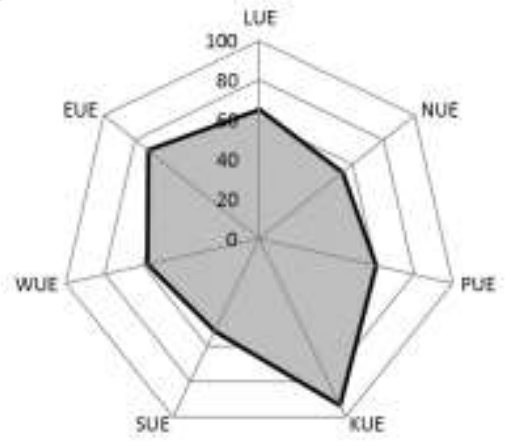

Ceres

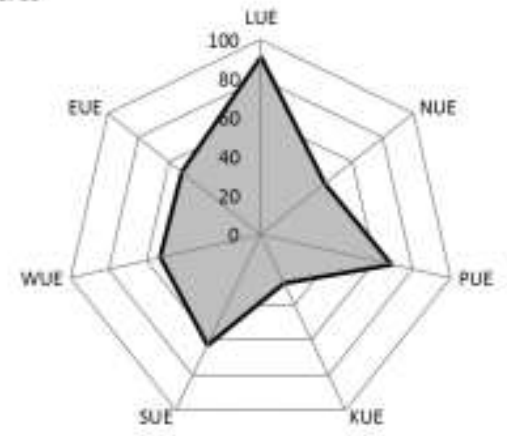

GT

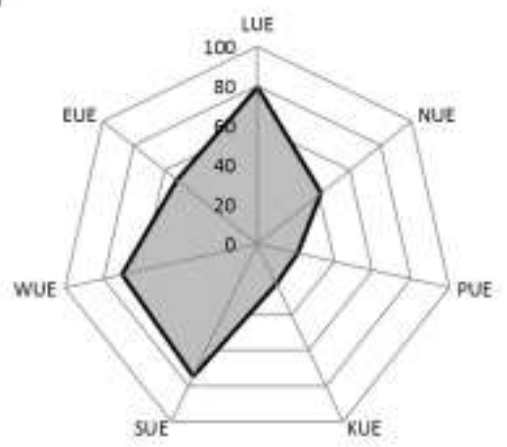

Fig. 6b: Radar diagrams illustrating the overall sustainability of NC, EC, LV Ceres, SWFS, GT and SCpotato production regions in South Africa, based on seven measured resource use efficiencies. Values are in percentages relative to the best performing region (100\%) with respect to each efficiency parameter. The larger the shaded area of a region, the higher the overall efficiency. See Table 2 for abbreviation of region names. 


\section{Concluding remarks}

The survey of potato growers across the various production regions in South Africa provided detailed and useful input data to assess on-farm resource use efficiencies, which can be used as indicators of ecological production sustainability. When presented together in a radar diagram, this information can serve as rapid and effective method for the visual assessment of overall sustainability of any farming or production system. This study revealed strong differences in the efficiencies of resource use (land, water, solar radiation, energy) between the sixteen potato growing regions assessed. The data indicated that these differences can be attributed to availability in resources (light and water), and the over- or under-application of resources, notably fertilizers and irrigation.

With regard to overall efficiency of production, there is a clear grouping of high input regions (e.g. Gauteng, Sandveld and Ceres), high efficiency regions (Mpumalanga Highveld, Southern Cape and Western Free State) and a low input region (Eastern Free State). The reasons for high input levels in regions differ, for example in the Sandveld and Ceres the very sandy soils lead to a high risk for water and nutrient leaching, resulting in higher use of these inputs. In Gauteng the socio-economic background of growers probably plays an important role: most are historically vegetable growers, who traditionally apply large amounts of manure to their fields, but these rates exceed the nutrient requirements of potatoes. This perhaps hints to less specialised knowledge on the potato crop. Some high efficiency regions (e.g. Southern Cape and Mpumalanga Highveld) are characterised by more favourable growing environments, including sandy loam soils, moderate air temperatures and high rainfall during the potato growing season, which favour potato production and reduce irrigation demand. However, it is interesting to note that some regions under pressure due to limited resources (e.g. Limpopo and South Western Free State that have limited water and high energy cost for irrigation and transport), tend to be among the most efficient. High input costs may thus stimulate farmers to become more efficient, even if environmental conditions are not optimal. 
Yields and input resource use efficiencies reported here are generally lower than those of western European countries (Darwish et al., 2006; Haase et al., 2007), but compare well to developing countries, such as the rest of Africa (Svubure et al., 2015) and South America. Although on average most resource use efficiencies reported in this study fall within the ranges reported for the rest of the world, variability is huge within and between regions and yield variability can often not be explained by the input levels used. A combination of lower production efficiency and higher production cost makes the South African potato sector less competitive and more vulnerable to competition by low cost imports. This study suggests that there is substantial room for improvement in production efficiency by better management on some farms. For example, irrigation and nutrient management can be improved through the use of decision support systems (e.g. for optimised fertilisation and irrigation scheduling). This will assist growers in making better strategic, tactical and operational decisions in order to improve sustainability, profitability and competitiveness of potato production.

\section{Acknowledgements}

This work was financially supported by Potatoes South Africa. The authors also wish to thank the producers who participated in the surveys and Pieter van Zyl, who supplied production and financial information.

\section{References}

Allen, R.G., Pereira, L.S., Raes, D., Smith, M., 1998. Crop evapotranspiration. FAO Paper No. 56. FAO, Rome, Italy.

Ati, A.S., lyada, A.D., Najim, S.M., 2012. Water use efficiency of potato (Solanum tuberosum L.) under different irrigation methods and potassium fertilizer rates. Ann. Agric. Sci. 57, 99-103

Badr, M.A., El-Tohamy, W.A., Zaghloul, A.M., 2012. Yield and water use efficiency of potato grown under different irrigation and nitrogen levels in an arid region. Agric. Water Manage. 110, 9-15. 
Caldiz, D.O., Gaspari, F.J., Haverkort, A.J., Struik, P.C., 2001. Agro-ecological zoning and potential yield of single or double cropping of potato in Argentina. Agric. For. Met. 109, 311-320.

Darwish, T.M., Atallah, T.W., Hajhasan, S., Haidar A., 2006. Nitrogen and water use efficiency of fertigated processing potato. Agric. Water Manage. 85, 95-104.

De Koeijer, T.J., Wossink, G.A.A., Smit, A.B., Janssens, S.R.M., Renkema, J.A., Struik, P.C., 2003. Assessment of the quality of farmers' environmental management and its effects on resource use efficiency: a Dutch case study. Agric. Syst. 78, 85-103.

De Vries, S.C., van de Ven, G.W.J., van Ittersum, M.K., Giller, K.E., 2010. Resource use efficiency and environmental performance of nine major biofuel crops, processed by first-generation conversion techniques. Biomass and Bioenergy. 34, $588-601$.

De Vries, S.C., van de Ven, G.W.J., van Ittersum, M.K., Giller, K.E., 2011. The production-ecological sustainability of cassava, sugarcane and sweet sorghum cultivation for bioethanol in Mozambique. GCB Bioenergy. 4, 20-35.

De Wit, C.T., 1992. Resource use efficiency in agriculture. Agric. Syst. 40, 125-151.

FAOSTAT, 2016. Food and Agriculture Organization of the United Nations. Statistics Division. http://faostat3.fao.org/download/Q/QC/E Accessed 24 May 2016.

Ferreira, T.C., Goncalves, D.A., 2007. Crop-yield/water-use production functions of potatoes (Solanum tuberosum, L.) grown under differential nitrogen and irrigation treatments in a hot, dry climate. Agric. Water Manage. 90, 45-55.

Franke, A.C., Steyn, J.M., Ranger, K.S., Haverkort, A.J., 2011. Developing environmental principles, criteria, indicators and norms for potato production through field surveys and modelling. Agric. Syst. 104, 297-306.

Franke, A.C., Haverkort, A.J., Steyn, J.M., 2013. Climate change and potato production in contrasting South African agro-ecosystems. 2. Assessing risks and opportunities of adaptation strategies. Potato Res. 56, 5166.

Haase, T., Schüler, C., Heß, J., 2007. The effect of different $\mathrm{N}$ and $\mathrm{K}$ sources on tuber nutrient uptake, total and graded yield of potatoes (Solanum tuberosum L.) for processing. Europ. J. Agron. 26, 187-197.

Haverkort, A.J., Franke, A.C., Steyn, J.M., Engelbrecht, F.A., 2013. Climate change and potato production in contrasting South African agro-ecosystems 1. Effects on land and water use efficiencies. Potato Res. 56, 3150. 
Haverkort, A.J., Franke, A.C., Steyn, J.M., Pronk, A.A., Caldiz, D.O, Kooman, P.L. 2015. A robust potato model: LINTUL-POTATO-DSS. Potato Res. 58, 313-327.

Haverkort, A.J., Hillier, J.G., 2011. Cool Farm Tool-Potato: Model description and performance of four production systems. Potato Res. 54, 355-369.

Haverkort, A.J., Struik, P.C., 2015. Yield levels of potato crops: Recent achievements and future prospects. Field Crops Res. 182, 76-85.

Haverkort, A.J., Sandana, P., Kalazich, J., 2014. Yield gaps and ecological footprints of potato production systems in Chile. Potato Res. 57, 13-31.

Hillier, J., Hawes, C., Squire, G., Hilton, A., Wale, S., Smith, P., 2009. The carbon footprints of food crop production. Int. J. Agric. Sust. 7, 107-118.

Hoffman, G., Salomez, J., 2000. Nitrogen and water - decision support systems. In: Haverkort, A.J., MacKerron, D.K.L. (Eds.), Management of nitrogen and water in potato production. Wageningen Press, Wageningen, The Netherlands. pp. 219-224.

Karam, F., Rouphael, Y., Lahoud, R., Breidi, J., Colla, G., 2009. Influence of genotypes and potassium application rates on yield and potassium use efficiency of potato. Agron. J. 8, 27-32.

Kooman, P.K., Haverkort, A.J., 1994. Modelling development and growth of the potato crop influenced by temperature and daylength: LINTUL-POTATO. In: Haverkort, A.J., MacKerron, D.K.L. (Eds.), Ecology and modeling of potato crops under conditions limiting growth. Kluwer Academic Publishers, Dordrecht, pp. 4160.

Lu, C.H., van Ittersum, M.K., Rabbinge, R., 2003. Quantitative assessment of resource-use efficient cropping systems: a case study for Ansai in the Loess Plateau of China. Europ. J. Agron. 19, 311-326.

Magliulo, V., Bindi, M., Rana, G., 2003. Water use of irrigated potato (Solanum tuberosum L.) grown under free air carbon dioxide enrichment in central Italy. Agric. Ecosyst. Environ. 97, 65-80.

Mason, S.J., Jury, M.R., 1997. Climatic variability and change over southern Africa: A reflection on underlying processes. Prog. Phys. Geogr. 21, 23-50.

Molahlehi, L., Steyn, J.M., Haverkort, A.J., 2013. Potato crop response to genotype and environment in a subtropical highland agro-ecology. Potato Res. 56, 237-258.

Molden, D., Oweis, T., Steduto, P., Bindraban, P., Hanjra, M.A., Kijne, J., 2010. Improving agricultural water productivity: Between optimism and caution. Agric. Water Manage. 97, 528-535. 
Nyagaka, D.O., Obare, G.A., Omiti, J.M., Nguyo, W., 2010. Technical efficiency in resource use: Evidence from smallholder Irish potato farmers in Nyandarua North District, Kenya. Afr. J. Agric. Res. 5, 1179-1186.

Onder, S., Caliskan, M.E., Onder, D., Caliskan, S., 2005. Different irrigation methods and water stress effects on potato yield and yield components. Agric. Water Manage. 73, 73-86.

Pieterse, B.J., Nel, J.J., 2012. The effect of plant population on yield. In: Denner, F.D.N., Venter, S.J., Niederwieser, J.G. (Eds.), Guide to potato production in South Africa. ISBN 978-1-86849-422-4. Potatoes South Africa, Pretoria, South Africa, pp 37-40.

Potatoes South Africa, 2015. South African potato industry - hectares and crop size. http://www.potatoes.co.za/SiteResources/documents/Hectares\%20vs\%20Crop\%20size,\%202014.JPG.

Accessed 24 August 2015.

Sincik, M, Turan, Z.M., Göksoy, A.T., 2008. Responses of potato (Solanum tuberosum L.) to green manure cover crops and nitrogen fertilization rates. Am. J. Pot Res. 85,150-158.

Steyn, J.M., Du Plessis, H.F., Fourie, P., Hammes, P.S., 1998. Yield response of potato genotypes to different soil water regimes in contrasting seasons of a subtropical climate. Potato Res. 41, 239-254.

Šrek, P., Hejcmana, M., Kunzováb, E., 2010. Multivariate analysis of relationship between potato (Solanum tuberosum L.) yield, amount of applied elements, their concentrations in tubers and uptake in a long-term fertilizer experiment. Field Crops Res. 118, 183-193.

Strydom, D., van Zyl, P., 2015. Price cost squeeze and production cost expectations for 2015 (original article in Afrikaans). Chips. 29(2), 60-66. http://www.potatoes.co.za/

Svubure, O., Struik, P.C., Haverkort, A.J., Steyn. J.M., 2015. Yield gap analysis and resource footprints of Irish potato production systems in Zimbabwe. Field Crops Res. 178, 77-90.

Tyson, P.D. 1986. Climatic change and variability in southern Africa. Cape Town: Oxford University Press.

van Asselt, E.D., van Bussel, L.G.J., van der Voet, H., van der Heijden, G.W.A.M., Tromp, S.O., Rijgersberg, H., van Evert, F., Van Wagenberg, C.P.A., van der Fels-Klerx., H.J. 2014. A protocol for evaluating the sustainability of agri-food production systems - A case study on potato production in peri-urban agriculture in The Netherlands. Ecol. Indicators 43, 315-321.

Van der Waals, J.E., Franke, A.C., Haverkort, A.J., Krüger, K., Steyn, J.M. 2013. Climate change and potato production in South Africa. 3. Effects on relative development rates of selected pests and pathogens. Potato Res. 56, 67-84. 
Van der Waals, J.E., Steyn, J.M., Franke, A.C., Haverkort, A.J., 2016. Grower perceptions of biotic and abiotic risks of potato production in South Africa. Crop Prot. 84, 44-55.

Van Zyl, P., van der Westhuizen, D., 2015. How capital intensive is potato production really? - Part 2 (original article in Afrikaans). Chips. 29(4), 74-77. http://www.potatoes.co.za/

Van Ittersum, M.K., Rabbinge, R., 1997. Concepts in production ecology for analysis and quantification of agricultural input-output combinations. Field Crops Res. 52, 197-208.

Van Ittersum, M.K., Cassman, K.G., Grassini, P., Wolf, J., Tittonell, P., Hochman, Z., 2013. Yield gap analysis with local to global relevance - a review. Field Crops Res.143, 4-17.

Van Halsema, G.E., Vincent, L., 2012. Efficiency and productivity terms for water management: A matter of contextual relativism versus general absolutism. Agric. Water Manage. 108, 9-15.

Van Loon, C.D., 1981. The effect of water stress on potato growth, development and yield. Am. J. Potato Res. $58,51-69$.

Vos, J., 2009. Nitrogen responses and nitrogen management in potato. Potato Res. 52, 305-317.

Zotarelli, L., Rens, L.R., Cantliffe, D.J., Stoffella, P.J., Gergela, D., Burhans, D., 2015. Rate and timing of nitrogen fertilizer application on potato 'FL1867'. Part I: Plant nitrogen uptake and soil nitrogen availability. Field Crops Res. 183, 246-256. 